\title{
PSEUDO-RIEMANNIAN SPACES WITH A SPECIAL RIEMANN TENSOR
}

\author{
O. Lesechko ${ }^{1}$, T. Shevchenko ${ }^{1}$ \\ ${ }^{1}$ Odessa State Academy of Civil Engineering and Architecture
}

\begin{abstract}
The paper considers pseudo-Riemannian spaces, the Riemann tensor of which has a special structure. The structure of the Riemann tensor is given as a combination of special symmetric and obliquely symmetric tensors. Tensors are selected so that the results can be applied in the theory of geodetic mappings, the theory of holomorphic-projective mappings of Kähler spaces, as well as other problems arising in differential geometry and its application in general relativity, mechanics and other fields.

Through the internal objects of pseudo-Riemannian space, others are determined, which are studied depending on what problems are solved in the study of pseudo-Riemannian spaces. By imposing algebraic or differential constraints on internal objects, we obtain special spaces. In particular, if constraints are imposed on the metric we will have equidistant spaces. If on the Ricci tensor, we obtain spaces that allow $\varphi$ (Ric)-vector fields, and if on the Einstein tensor, we have almost Einstein spaces.

The paper studies pseudo-Riemannian spaces with a special structure of the curvature tensor, which were introduced into consideration in I. Mulin paper. Note that in his work these spaces were studied only with the requirement of positive definiteness of the metric. The proposed approach to the specialization of pseudo-Riemannian spaces is interesting by combining algebraic requirements for the Riemann tensor with differential requirements for its components.

In this paper, the research is conducted in tensor form, without restrictions on the sign of the metric. Depending on the structure of the Riemann tensor, there are three special types of pseudoRiemannian spaces. The properties which, if necessary, satisfy the Richie tensors of pseudoriman space and the tensors which determine the structure of the curvature tensor are studied.

In all cases, it is proved that special tensors satisfy the commutation conditions together with the Ricci tensor. The importance and usefulness of such conditions for the study of pseudo-Riemannian spaces is widely known. Obviously, the results can be extended to Einstein tensors. Proven theorems allow us to effectively investigate spaces with constraints on the Ricci tensor.
\end{abstract}

Keywords: pseudo-Riemannian spaces, geodesic mapping, the Ricci tensor.

\section{ПСЕВДОРІМАНОВІ ПРОСТОРИ ЗІ СПЕЦАЛЬНОЮ СТРУКТУРОЮ ТЕНЗОРА РІМАНА}

\author{
Лесечко О. В. ${ }^{\mathbf{1}}$, Шевченко Т. I. $^{\mathbf{1}}$ \\ ${ }^{1}$ Одеська державна академія будівництва та архітектури
}

Анотація: В роботі розглянуті псевдоріманові простори, тензор Рімана яких, має спеціальну структуру. Структура тензора Рімана задається як комбінація спеціальних симетричних та кососиметричних тензорів. Вибрані тензори так, щоб результати можна було застосувати в теорії геодезичних відображень, теорії голоморфно-проективних відображень келерових просторів, а також інших задачах, що виникають в диференціальній геометрії та при iї застосуванні в загальній теорії відносності, механіці та інших областях.

Через внутрішні об'єкти псевдоріманового простору визначаються інші, які вивчаються в залежності від того, які задачі розв'язуються при дослідженні псевдоріманових просторів. Накладаючи обмеження алгебраїчного чи диференціального характеру на внутрішні об'єкти, отримуємо спеціальні простори. Зокрема, якщо обмеження накладаються на метрику будемо мати еквідістантні простори. Якщо на тензор Річчі, отримаємо простори, що допускають 
$\varphi($ Ric)-векторні поля, а якщо на тензор Ейнштейна, то будемо мати майже ейнштейнові простори.

В роботі вивчаються псевдоріманові простори зі спеціальною структурою тензора кривини, які були введені в розгляд в статті I. Муліна. Зауважимо, що в його роботі вказані простори вивчались лише з вимогою додатної визначенності метрики. Запропонований підхід до спеціалізації псевдоріманових просторів цікавий поєднанням алгебраїчних вимог на тензор Рімана $з$ диференціальними вимогами на його складові.

В даній роботі дослідження ведуться в тензорній формі, без обмежень на знак метрики. В залежності від структури тензора Рімана виділені три спеціальні типи псевдоріманових просторів. Вивчаються властивості, яким за необхідністю задовольняють тензори Річчі псевдоріманового простору та тензори, які визначають структуру тензора кривини.

У всіх випадках доведено, що спеціальні тензори задовольняють разом з тензором Річчі умовам комутації. Важливість і корисність таких умов для досліджень псевдоріманових просторів широко відома. Очевидно, що результати можуть бути поширені на тензори Ейнштейна. Доведені теореми дозволяють ефективно досліджувати простори з обмеженнями на тензор Річчі.

Ключові слова: псевдоримановы пространства, геодезические отображения, тензор Річчі. 


\section{INTRODUCTION}

The work treats special pseudo-Riemannian spaces $V_{n}$ having a metric tensor $g_{i j}$.

Object, which are calculated basing on the metric tensor $g_{i j}$, are called inner objects of the space $V_{n}$.

They include Christo el's symbols of the rst kind

$$
2 \Gamma_{i j k}=\partial_{i} g_{j k}+\partial_{j} g_{i k}-\partial_{k} g_{i j},
$$

and those of the second kind

$$
\Gamma_{i j}^{h}=g^{\alpha h} \Gamma_{i j \alpha},
$$

Riemann tensor

$$
R_{i j k}^{h}=\partial_{j} \Gamma_{i k}^{h}+\Gamma_{i k}^{\alpha} \Gamma_{j \alpha}^{h}-\partial_{k} \Gamma_{i j}^{h}-\Gamma_{i j}^{\alpha} \Gamma_{k \alpha}^{h},
$$

Ricci tensor

$$
R_{i j \alpha}^{\alpha}=R_{i j},
$$

scalar curvature

$$
R=R_{\alpha \beta} g^{\alpha \beta},
$$

here $g^{i j}$ are elements of invertible matrix for a metric tensor $g_{i j}$.

These objects lay a foundation for de nition of other objects, which come in focus of our attention depending on the problem we are currently solving, for example Einstein tensor.

$$
E_{i j}=R_{i j}-\frac{R}{n} g_{i j} \text {. }
$$

Imposing some limitations of algebraic or di erential kind on the inner objects, we are able to de ne special pseudo-Riemannian limitations, namely: limitations imposed on the metric result in equidistant spaces [2], on the Ricci tensor - spaces permitting $\varphi(R i c)$-vector fields [6, 9], on Einstein tensor - quasi-Einstein spaces [8, 14, 15].

A profound review of special pseudo-Riemannian spaces with limitations imposed on the Riemann tensor can be found in the work [21].

This paper treats pseudo-Riemannian spaces with a curvature tensor having a particular structure. They were introduced in the article [19].

Let us not, that the latter work was centered on the spaces limited by request of positivedefinite metrics [17, 20, 22, 23].

Here, we carry out our research without any limitations on a sign of a metric.

\section{TYPES OF SPECIAL PSEUDO-RIEMANNIAN SPACES}

I. Mulin in the work [19] introduced the following three types of special Riemannian spaces

I type:

$$
R_{i j k l}=\alpha\left(g_{i k} g_{j l}-g_{i l} g_{j k}\right)+\beta\left(u_{i k} u_{j l}-u_{i l} u_{j k}\right)+\gamma\left(v_{i k} v_{j l}-v_{i l} v_{j k}\right),
$$

here $\alpha, \beta, \gamma$ are some constantsand symmetrical tensors uij and vij comply with conditions

$$
u_{i j, k}=\sigma_{k}^{1} g_{i j}+\sigma_{k}^{2} u_{i j}+\sigma_{k}^{3} v_{i j},
$$




$$
v_{i j, k}=\tau_{k}^{1} g_{i j}+\tau_{k}^{2} u_{i j}+\tau_{k}^{3} v_{i j} \text {, }
$$

here $\stackrel{1}{\sigma_{i}}, \stackrel{2}{\sigma_{i}}, \stackrel{3}{\sigma_{i}}, \stackrel{1}{\tau_{i}}, \stackrel{2}{\tau_{i}}, \stackrel{3}{\tau_{i}}$ are some vectors, comma - a sign of covariant derivative by connectivity $V_{n}$

II type:

$$
R_{i j k l}=\alpha\left(p_{i k} p_{j l}-p_{i l} p_{j k}\right)+\beta\left(s_{i k} s_{j l}-s_{j k} s_{i l}+\lambda s_{i j} s_{k l}\right),
$$

here $\alpha, \beta$ are some constants; $p_{i j}, s_{i j}$ are symmetric and skew symmetric tensors, respectively, that comply with conditions

$$
\begin{aligned}
& p_{i j, k}=\sigma p_{i j}, \\
& s_{i j, k}=\tau_{k} s_{i j},
\end{aligned}
$$

here $\sigma_{i}, \tau_{i}$ are some vectors.

III type:

$$
R_{i j k l}=\alpha\left(r_{i k} r_{j l}-r_{j k} r_{i l}+\lambda r_{i j} r_{k l}\right)+\beta\left(s_{i k} s_{j l}-s_{j k} s_{i l}+\mu s_{i j} s_{k l}\right) \text {, }
$$

here $\alpha, \beta, \lambda, \mu$ are scalars; $r_{i j}, s_{i j}$ are skew symmetrical tensors selected in such a way that

$$
\begin{aligned}
& r_{i j, k}=\stackrel{1}{\rho_{k}} r_{i j}+\stackrel{2}{\rho} s_{k}, \\
& s_{i j, k}=\stackrel{1}{\theta_{k}} r_{i j}+\stackrel{2}{\theta_{k}} s_{i j},
\end{aligned}
$$

here $\stackrel{1}{\rho_{i}}, \stackrel{2}{\rho_{i}}, \stackrel{1}{\theta_{i}}, \stackrel{2}{\theta_{i}}$ are some vectors.

\section{PSEUDO-RIEMANNIAN SPACES OF THE FIRST TYPE}

Integrability conditions (8) and (9) take a shape of the following

$$
\begin{aligned}
& u_{\alpha i} R_{j k l}^{\alpha}+u_{\alpha j} R_{i k l}^{\alpha}=g_{i j}\left(\sigma_{k l}^{1}-\sigma_{l k}+\sigma_{k}^{2} \sigma_{l}-\sigma_{l}^{2} \sigma_{k}+\frac{1}{\tau_{l}} \sigma_{k}-\tau_{k} \sigma_{l}^{3}\right)+ \\
& +u_{j i}\left(\sigma_{k l}^{2}-\sigma_{l k}^{2}+\sigma_{k}^{3} \tau_{l}^{2}-3_{1}^{2} \tau_{k}^{2}\right)+v_{j i}\left(\sigma_{k l}^{3}-\sigma_{l k}^{3}+\sigma_{k}^{2}{ }^{3} \sigma_{l}-\sigma_{l}^{2} \sigma_{k}+\sigma_{k} \tau_{l}^{3}-\sigma_{l}^{3} \tau_{k}^{3}\right),
\end{aligned}
$$

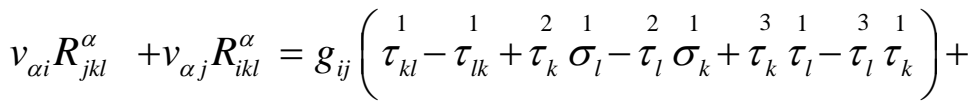

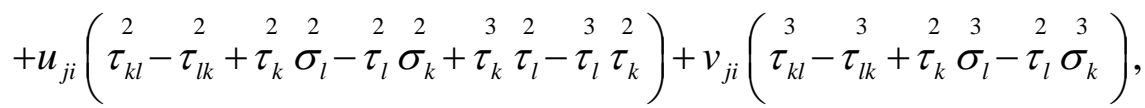

here ${\stackrel{\alpha}{\sigma_{i j}}}^{\alpha}{ }_{\sigma_{i, j}}^{\alpha} ; \stackrel{\alpha}{\tau}_{i j}=\tau_{i, j}^{\alpha} ; \quad \alpha=1,2,3$.

Wrapping (16) and (17) by indices $i, j$, we get, respectively

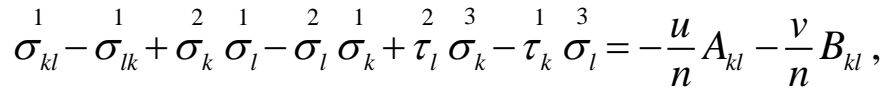

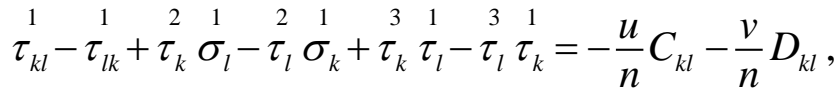

where 


$$
\begin{aligned}
& A_{k l}=\sigma_{k l}^{2}-\sigma_{l k}^{2}+\sigma_{k} \tau_{l}^{2}-\sigma_{l} \tau_{k}^{2}, \\
& B_{k l}=\sigma_{k l}^{3}-\sigma_{l k}+\sigma_{k}^{2} \sigma_{l}-\sigma_{l}^{2} \sigma_{k}+\sigma_{k} \tau_{l}-\sigma_{l}^{3} \tau_{k}, \\
& C_{k l}=\tau_{k l}^{2}-\tau_{l k}^{2}+\tau_{k}^{2} \sigma_{l}^{2}-\tau_{l}^{2} \sigma_{k}^{2}+\tau_{k} 2_{l}^{2}-\tau_{l} \tau_{k}^{2}, \\
& D_{k l}=\tau_{k l}^{3}-\tau_{l k}^{3}+\tau_{k}^{2} \sigma_{l}-\tau_{l}^{2} \sigma_{k}, \\
& u=u_{\alpha \beta} g^{\alpha \beta} ; \quad v=v_{\alpha \beta} g^{\alpha \beta} .
\end{aligned}
$$

Then, (16) and (17) can be re-written as follows

$$
\begin{aligned}
& u_{\alpha i} R_{j k l}^{\alpha}+u_{\alpha j} R_{i k l}^{\alpha}=a_{i j} A_{k l}+b_{i j} B_{k l}, \\
& v_{\alpha i} R_{j k l}^{\alpha}+v_{\alpha j} R_{i k l}^{\alpha}=a_{i j} C_{k l}+b_{i j} D_{k l},
\end{aligned}
$$

here

$$
a_{i j}=u_{i j}-\frac{u}{n} g_{i j} ; b_{i j}=v_{i j}-\frac{v}{n} g_{i j} .
$$

Cycling (20) and (21) by indices $i, k, l$

$$
\begin{aligned}
& u_{\alpha i} R_{j k l}^{\alpha}+u_{\alpha k} R_{j l i}^{\alpha}+u_{\alpha l} R_{j i k}^{\alpha}=a_{i j} A_{k l}+a_{k j} A_{l i}+a_{l i} A_{i k}+b_{i j} B_{k l}+b_{k j} B_{l i}+b_{l j} B_{i k}, \\
& v_{\alpha i} R_{j k l}^{\alpha}+v_{\alpha k} R_{j l i}^{\alpha}+v_{\alpha l} R_{j i k}^{\alpha}=a_{i j} C_{k l}+a_{k j} C_{l i}+a_{l i} C_{i k}+b_{i j} D_{k l}+b_{k j} D_{l i}+b_{l j} D_{i k} .
\end{aligned}
$$

Wrapping by indices $i, j$, we obtain, respectively

$$
\begin{aligned}
& u_{\alpha l} R_{k}^{\alpha}-u_{\alpha k} R_{l}^{\alpha}=a_{l \alpha} A_{k}^{\alpha}-a_{k \alpha} A_{l}^{\alpha}+b_{l \alpha} B_{k}^{\alpha}-b_{k \alpha} B_{l}^{\alpha}, \\
& v_{\alpha l} R_{k}^{\alpha}-v_{\alpha k} R_{l}^{\alpha}=a_{l \alpha} C_{k}^{\alpha}-a_{k \alpha} C_{l}^{\alpha}+b_{l \alpha} D_{k}^{\alpha}-b_{k \alpha} D_{l}^{\alpha},
\end{aligned}
$$

where $A_{j}^{i}=A_{\alpha j} g^{\alpha i} ; B_{j}^{i}=B_{\alpha j} g^{\alpha i} ; C_{j}^{i}=C_{\alpha j} g^{\alpha i} ; D_{j}^{i}=D_{\alpha j} g^{\alpha i}$.

Taking into account (7) the equation (20) can be written down in the following form.

$$
\begin{aligned}
& \alpha\left(u_{i k} g_{j l}-u_{i l} g_{j k}+u_{j k} g_{i l}-u_{j l} g_{i k}\right)+\beta\left(u_{i \alpha} u_{k}^{\alpha} u_{j l}-u_{i \alpha} u_{l}^{\alpha} u_{j k}+u_{j \alpha} u_{k}^{\alpha} u_{i l}-u_{j \alpha} u_{l}^{\alpha} u_{i k}\right)+ \\
& +\gamma\left(u_{i \alpha} v_{k}^{\alpha} v_{j l}-u_{i \alpha} v_{l}^{\alpha} v_{j k}+u_{j \alpha} v_{k}^{\alpha} v_{i l}-u_{j \alpha} v_{l}^{\alpha} v_{i k}\right)=a_{i j} A_{k l}+b_{i j} B_{k l} .
\end{aligned}
$$

Wrapping the latter by indices $j, k$ and alternating by indices $i, l$ :

$$
a_{\alpha l} A_{k}^{\alpha}-a_{k \alpha} A_{l}^{\alpha}+b_{l \alpha} B_{k}^{\alpha}-b_{k \alpha} B_{l}^{\alpha}=0 .
$$

Analogous equation can be obtained also for the equations (25).

Substituting it into (24) and (25), it is easy to see that the following statement is true.

Lemma 1. Tensors $u_{i j}$ and $v_{i j}$ satisfy the conditions

$$
\begin{aligned}
& u_{\alpha i} R_{j}^{\alpha}-u_{\alpha j} R_{i}^{\alpha}=0, \\
& v_{\alpha i} R_{j}^{\alpha}-v_{\alpha j} R_{i}^{\alpha}=0 .
\end{aligned}
$$

\section{PSEUDO-RIEMANNIAN SPACES OF THE SECOND TYPE}

Integrability conditions (11) and (12) are as follows

$$
\begin{aligned}
& p_{\alpha i} R_{j k l}^{\alpha}+p_{\alpha j} R_{i k l}^{\alpha}=\left(\sigma_{k, l}-\sigma_{l, k}\right) p_{i j}, \\
& s_{\alpha j} R_{i k l}^{\alpha}+s_{i \alpha} R_{j k l}^{\alpha}=\left(\tau_{k, l}-\tau_{l, k}\right) s_{i j} .
\end{aligned}
$$

Wrapping (30) by indices $i$, $j$, we can see that, when $p=p_{\alpha \beta} g^{\alpha \beta} \neq 0$, then 


$$
\sigma_{k, l}-\sigma_{l, k}=0 \text {, }
$$

or, in other words vector $\sigma_{i}$ a gradient vector with a necessity. Then, equation (30), can be re-written in the following form

$$
p_{\alpha i} R_{j k l}^{\alpha}+p_{\alpha j} R_{i k l}^{\alpha}=0 \text {. }
$$

Cycling (10) by indices $j, k, l$ and taking into account the properties of Ricci tensor, reducing terms, we obtain

$$
(2-\lambda)\left(s_{i k} s_{j l}+s_{i j} s_{l k}+s_{i l} s_{k j}\right)=0 .
$$

When $\lambda=2$, then (10) takes the following shape

$$
R_{i j k l}=\alpha\left(p_{i k} p_{j l}-p_{i l} p_{j k}\right)+\beta\left(s_{i k} s_{j l}-s_{j k} s_{i l}+2 s_{i j} s_{k l}\right) \text {. }
$$

Wrapping by indices $j, k$, we arrive at

$$
R_{i l}=\alpha\left(p_{i \alpha} p_{l}^{\alpha}-p_{i l} p\right)+3 \beta s_{i \alpha} s_{l}^{\alpha},
$$

here $p_{j}^{i}=p_{\alpha j} g^{\alpha i} ; \quad s_{j}^{i}=s_{\alpha j} g^{\alpha i}$.

When the equation (34) contains $\lambda \neq 2$, then

$$
S_{i k} S_{j l}+S_{i j} S_{l k}+S_{i l} S_{k j}=0 \text {. }
$$

Let us select vectors $\xi^{j}$ and $\xi^{l}$, in such a way, that $s_{\alpha \beta} \xi^{\alpha} \xi^{\beta}=1$, then, basing on the (37), we get

$$
S_{i k}=a_{i} b_{k}-a_{k} b_{i},
$$

where $a_{i}=s_{\alpha i} \xi^{\alpha} ; b_{i}=s_{\alpha i} \eta^{\alpha}$.

Let us substitute (38) in (10), we obtain

$$
R_{i j k l}=\alpha\left(p_{i k} p_{j l}-p_{i l} p_{j k}\right)+\beta(\lambda+1) s_{i j} s_{k l} .
$$

Lemma 2. Riemann tensor obtains a form of (35)or (39) for the spaces of the second type. Cycling (33)) by indices $j, k, l$, we obtain

$$
p_{\alpha j} R_{i k l}^{\alpha}+p_{\alpha k} R_{i l j}^{\alpha}+p_{\alpha l} R_{i j k}^{\alpha}=0 .
$$

Wrapping by indices $i, k$, we get

$$
p_{\alpha i} R_{j}^{\alpha}-p_{\alpha j} R_{i}^{\alpha}=0 \text {. }
$$

By an application of the approach, which was used to study spaces of the first type, we are able to see:

$$
S_{\alpha i} R_{j}^{\alpha}-S_{\alpha j} R_{i}^{\alpha}=0 \text {. }
$$

\section{PSEUDO-RIEMANNIAN SPACES OF THE THIRD TYPE}

Cycling (13) and applying the above-mentioned methods, we get three main cases

a) when $\lambda=\mu=2$

$R_{i j k l}=\alpha\left(r_{i k} r_{j l}-r_{j k} r_{i l}+2 r_{i j} r_{k l}\right)+\beta\left(s_{i k} s_{j l}-s_{j k} s_{i l}+2 s_{i j} s_{k l}\right)$.

b) when $\lambda=2, \mu \neq 2$ 
$R_{i j k l}=\alpha\left(r_{i k} r_{j l}-r_{j k} r_{i l}+2 r_{i j} r_{k l}\right)+\beta(\mu+1) s_{i j} s_{k l}$.

c) when $\lambda \neq 2, \mu \neq 2$

$R_{i j k l}=\alpha(\lambda+1) r_{i j} r_{k l}+\beta(\mu+1) s_{i j} s_{k l}$.

Integrability conditions for equations (14) and taking account (15), we get

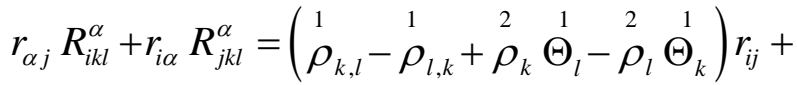

$$
\begin{aligned}
& +\left(\begin{array}{l}
2 \\
\rho_{k, l}
\end{array}-\stackrel{2}{\rho_{l, k}}+\stackrel{1}{\rho_{k}} \stackrel{2}{\rho}_{l}-\stackrel{1}{\rho}_{l} \stackrel{2}{\rho}_{k}+\stackrel{2}{\rho_{k}} \stackrel{2}{\Theta}_{l}-\stackrel{2}{\rho_{l}} \stackrel{2}{\Theta}_{k}\right) S_{i j} .
\end{aligned}
$$

Analogous conditions can be obtained for the tensor $s_{i j}$, applying expressions (15) and (14).

Applying the methods, which were used for the first and the second type, and taking into account the equations (43), (44), (45) we can see for every case that

$$
\begin{aligned}
& r_{\alpha i} R_{j}^{\alpha}-r_{\alpha j} R_{i}^{\alpha}=0, \\
& s_{\alpha i} R_{j}^{\alpha}-s_{\alpha j} R_{i}^{\alpha}=0 .
\end{aligned}
$$

Thus, the following statement is true:

Theorem. The following conditions (47), (48) are true for pseudo-Riemannian spaces of the third type.

\section{CONCLUSIONS}

The work is devoted to the study of pseudo-Riemannian spaces with the Riemann tensor of a particular structure. Riemann tensor's structure is de ned by combinations of special symmetric and skew symmetric tensors. The tensors are selected in such a way, which would permit the application of results in the theory of geodesic mappings, theory of holomorphic projective mappings of Kahler spaces and in other geometric problems [1, 3, 7, 10, 16].

It is proved for every type of these spaces that the special tensors jointly with Ricci tensor are connected by a relation of commutation. These conditions are extremely important for a study of pseudo-Riemannian spaces, namely they can be fruitfully applied for the latter $[11,12,13]$. The further research should proceed by extension of these conditions to the Einstein tensors.

\section{References}

1. Bolsinov, A. V., Kiosak, V. A. Matveev, V. S. (2009). A Fubini Theorem for pseudo-Riemannian metrics. Journal of the London Mathematical Society. 80 (2). 341-356.

2. Evtushik, L., Kiosak, V., Mikes, J. (2010). The mobility of Riemannian spaces with respect to conformal mappings onto. Einstein spaces Russian Mathematics. 54(80). 29-33.

3. Fedorova, A., Kiosak, V., Matveev, V., Rosemann, S. (2012). The only Kahler manifold wi- th degree of mobility at least 3 is (CP(n), g Fubini-Study). Proceedings of the London Mathematical Society. Volume 105. Issue 1. 153-188. https://doi.org/10.1112/plms/pdr053

4. Gladish, B. I., Prishlyak, O. O. (2016). Functions with nondegerated critical ponts on the boundary of the surface. Ukrainian Math. J. 68(1). 29-40.

5. Gladish, B. I., Prishlyak, O. O. (2017). Topology of functions with isolated critical points on the boundary of a 2-dimensional manifold. Symmetry, Integrability and Geometry: Methods and Applications (SIGMA). 13. 50. doi: 10.3842/SIGMA.2017.050

6. Hinterleitner, I., Kiosak, V. (2008). $\varphi$ (Ric) Vector Fields in Riemannian Spaces. Archivummathematicum. Brno. 44(5). 385-390.

7. Hinterleitner, I., Kiosak, V. (2010). Special Einstein's equations on Kahler manifolds. Archivum Mathematicum. 46(5). 333-337. 
8. Kiosak, V. A. (2012). On the conformal mappings of quasi-Einstein spaces. Journal of Mathematical Sciences. United States. 184(1). 12-18.

9. Kiosak, V. Hinterleitner, I. (2009). $\varphi$ (Ric)-Vector Fields on Conformally Flat Spaces. Proceedings of American Institute of Physics. 1191(98). 98-103. https://doi.org/10.1063/1.3275604.

10.Kiosak, V. A., Kovalova, V. S. (2020). Geodesic mappings of quasi-Einstein spaces with a constant scalar curvature. Matematychni Studii. 53(2). 212-217. https://doi.org/10.30970/ms.53.2.212-217.

11.Kiosak, V., Lesechko, O., Savchenko, O. (2018). Mappings of Spaces with Affine Connection. 17th Conference on Applied Mathematics. APLIMAT 2018 - Procedings. Bratislava. 563-569.

12.Kiosak, V., Matveev, V. (2014). There exist no 4-dimensional geodesically equivalent metrics with the same stress-energy tensor. Journal of Geometry and Physics. 78. 1-11. doi:10.1016/j.geomphys.2014.01.002.

13.Kiosak, V. A., Matveev, V. S., Mikes, J., Shandra, I. G. (2010). On the degree of geodesic mobility for Riemannian metrics. Mathematical Notes. 87(4). 586-587. https://doi: 10.1134/S000143461003 0375.

14.Kiosak, V., Savchenko, A., Gudyreva, O. (2019). On the conformal mappings of special quasiEinstein spaces. AIP Conference Procedings. 2164 (040001). https://doi.org/10.1063/1.5130793.

15.Kiosak, V., Savchenko, A., Kovalova, G. (2020). Geodesic mappings of compact quasi- Einstein spaces, I. Proceedings of the International Geometry Center. 13 (1). 35-48. https://doi.org/10.15673/tmgc.v13i1.1711.

16.Kiosak, V., Savchenko, A., Shevchenko, T. (2018). Holomorphically Projective Mappi- ngs of Special Kahler Manifolds. AIP Conference Procedings. 2025 (08004). https://doi.org/10.1063/1.5064924.

17.Lesechko, O., Latysh, O., Kamienieva, A. (2019). Models of Mechanical Systems Preserving the Weyl Tensor. AIP Conference Proceedings. 2164 (040002). doi:10.1063/1.5130794.

18.Mikes, J., Hinterleitner, I., Kiosak, V. A. (2006). On the Theory of Geodesic Mappings of Einstein Spaces and their Generalizations. AIP Conference Proceedings. 861 (2006). 428-435. https://doi.org/10.1063/1.2399606.

19.Mulin, I.G. (1973). On some classes of Riemannian spaces with a special structure of the curvature tensor. Ukrainskii geometricheskii sbornik. 14. 56-64.

20.Prishlyak, O. O. (2007). Complete topological invariants of Morse-Smale ows and handle decompositions of 3-manifolds. Journal of Mathematical Sciences.

21.Sinyukov, N. S. (1979). Geodezicheskie otobrazheniya rimanovykh prostranstv. [Geodesic mappings of Riemannian spaces]. Moskva: Nauka.[in Russian].

22.Vasilenko, A. T., Lesechko, A. V. (1996). Nonlinear nonaxisymmetric deformation of composite shells of revolution. Journal of Mathematical Sciences. 79 (6). 1458-1461.

23.Zarichnyi, M., Savchenko, A., Kiosak, V. (2019). Strong topology on the set of persistence diagrams. AIP Conference Procedings. 2164 (040006). https://doi.org/10.1063/1.5130798.

\section{Література}

1. Bolsinov A. V., Kiosak V. A. Matveev V. S. A Fubini Theorem for pseudo-Riemannian metrics. Journal of the London Mathematical Society. 2009. 80(2). pp. 341-356.

2. Evtushik L., Kiosak V., Mikes J. The mobility of Riemannian spaces with respect to conformal mappings onto. Einstein spaces Russian Mathematics. 2010. 54 (80). pp.29-33.

3. Fedorova A., Kiosak V., Matveev V., Rosemann S. The only Kahler manifold wi- th degree of mobility at least 3 is (CP(n), g Fubini-Study). Proceedings of the London Mathematical Society, 2012. Volume 105. Issue 1. pp. 153-188. https://doi.org/10.1112/plms/pdr053

4. Gladish B. I., Prishlyak O. O. Functions with nondegerated critical ponts on the boundary of the surface. Ukrainian Math J. 2016. 68(1). pp. 29-40.

5. Gladish B. I., Prishlyak O. O. Topology of functions with isolated critical points on the boundary of a 2-dimensional manifold. Symmetry, Integrability and Geometry: Methods and Applications (SIGMA). 2017. 13. 50. doi: 10.3842/SIGMA.2017.050

6. Hinterleitner I., Kiosak V. $\varphi($ Ric) Vector Fields in Riemannian Spaces. Archivum- mathematicum. Brno. 2008. 44(5). pp. 385-390. 
7. Hinterleitner I., Kiosak V. Special Einstein's equations on Kahler manifolds. Archivum Mathematicum. 2010. 46(5). pp. 333-337.

8. Kiosak V. A. On the conformal mappings of quasi-Einstein spaces. Journal of Mathematical Sciences. United States. 2012. 184(1). pp. 12-18.

9. Kiosak V. Hinterleitner I. $\varphi$ (Ric)-Vector Fields on Conformally Flat Spaces. Proceedings of American Institute of Physics. 2009. 1191(98). pp. 98-103. https://doi.org/10.1063/1.3275604.

10.Kiosak V. A., Kovalova V. S. Geodesic mappings of quasi-Einstein spaces with a constant scalar curvature. Matematychni Studii. 2020. 53(2). pp. 212-217. https://doi.org/10.30970/ms.53.2.212217.

11.Kiosak V., Lesechko O., Savchenko O. Mappings of Spaces with Affine Connection. 17th Conference on Applied Mathematics. APLIMAT 2018 - Procedings, Bratislava. 2018. pp. 563-569.

12.Kiosak V., Matveev V. There exist no 4-dimensional geodesically equivalent metrics with the same stress-energy tensor. Journal of Geometry and Physics. 2014. 78. pp. 1-11. doi:10.1016/j.geomphys.2014.01.002.

13.Kiosak V. A., Matveev V. S., Mikes J., Shandra I. G. On the degree of geodesic mobility for Riemannian metrics. Mathematical Notes. 2010. 87(4). pp. 586-587. https://doi: 10.1134/S0001434610030375.

14.Kiosak V., Savchenko A., Gudyreva O. On the conformal mappings of special quasi-Einstein spaces. AIP Conference Procedings. 2019. 2164 (040001). https://doi.org/10.1063/1.5130793.

15.Kiosak V., Savchenko A., Kovalova G. Geodesic mappings of compact quasi- Einstein spaces, I. Proceedings of the International Geometry Center. 2020. 13 (1), pp. 35-48. https://doi.org/10.15673/tmgc.v13i1.1711.

16.Kiosak V., Savchenko A., Shevchenko T. Holomorphically Projective Mappi- ngs of Special Kahler Manifolds. AIP Conference Procedings. 2018. 2025 (08004). https://doi.org/10.1063/1.5064924.

17.Lesechko O., Latysh O., Kamienieva A. Models of Mechanical Systems Preserving the Weyl Tensor. AIP Conference Proceedings. 2019. 2164 (040002). doi:10.1063/1.5130794.

18.Mikes J., Hinterleitner I., Kiosak V. A. On the Theory of Geodesic Mappings of Ei- nstein Spaces and their Generalizations. AIP Conference Proceedings. 2006. 861 (2006). pp. 428-435. https://doi.org/10.1063/1.2399606.

19.Mulin I.G. On some classes of Riemannian spaces with a special structure of the curvature tensor. Ukrainskii geometricheskii sbornik. 1973. 14. pp. 56-64.

20.Prishlyak O. O. Complete topological invariants of Morse-Smale ows and handle decompositions of 3-manifolds. Journal of Mathematical Sciences. 2007.

21.Синюков Н.С. Геодезические отображения римановых пространств. М.: Наука. Главная редакция физико-математической литературы, 1979. 256 с.

22.Vasilenko A. T., Lesechko A. V. Nonlinear nonaxisymmetric deformation of composite shells of revolution. Journal of Mathematical Sciences. 1996. 79 (6). pp. 1458-1461.

23.Zarichnyi M., Savchenko A., Kiosak V. Strong topology on the set of persistence diagrams. AIP Conference Procedings. 2019. 2164 (040006). https://doi.org/10.1063/1.5130798.

\section{Lesechko Oleksandr}

Odesa State Academy of Civil Engineering and Architecture, Ph.D., Assosiate professor Didrihsona str., 4Ukraine 65029, a.lesechko@ukr.net, ORCID: 0000-0002-2352-6174

Shevchenko Tatiana

Odesa State Academy of Civil Engineering and Architecture, Ph.D., Assosiate professor

Didrihsona str., 4Ukraine 65029, shevat11@gmail.com, ORCID: 0000-0002-7304-1706

For references:

Lesechko O, Shevchenko T. (2021). Pseudo-riemannian spaces with a special Riemann tensor. Mechanics and Mathematical Methods. 3 (1). 106-114.

Для посилань:

Лесечко О.В., Шевченко Т.I. Псевдоріманові простори зі спеціальною структурою тензора Рімана. Механіка та математичні методи, 2021. Т. 3. № 1. С. 106-114. 